\title{
Liability Insurers and Third-Party Claimants: The Limits of Duty
}

Liability insurance is a curious phenomenon. Originally a simple contract to indemnify the insured, it has evolved into a complex undertaking to protect him from suit by deciding when and how much to pay persons he has injured. Originally an arm's length transaction between businessmen, it has become a relationship in which most insureds are unsophisticated consumers in need of protection from misrepresentation and overreaching. Originally an essentially private agreement, it has become the vehicle by which society achieves the dual goals of aiding victims of accidents and spreading the costs of accidents among people who derive benefit from accident-causing activities. As a result of these transformations, most problems in liability insurance can no longer be solved by traditional contract analysis, but call for the application of tort doctrines, statutory construction, and considerations of public policy.

This comment addresses one such problem in liability insurance law. An insurer that wrongfully refuses an injured party's offer to settle a claim against its policyholder for an amount within policy limits can be liable to the policyholder, if a judgment in excess of policy limits is subsequently entered against him. The question is whether the same refusal of a settlement offer and the same judgment in excess of insurance coverage should also entitle the injured party to sue the liability insurer.

Most states do not allow the third-party claimant to proceed against the insurer, once he has been paid the maximum recoverable on the policy, except as the policyholder's assignee. Some states, however, have altered this result either by using statutes to create an assignment where the policyholder has not voluntarily made one, or by fashioning a direct third-party suit against the insurer.

This comment first examines the insured's bad-faith suit as the predicate on which third-party claims are based. It concludes that the action is fundamentally sound and necessary, but that it should be confined rather than expanded. The comment then explores the theoretical justifications for the third-party suit and the 
difficulties such an action can be expected to generate. It next surveys the efforts of courts and commentators to find a direct action based on preexisting law, none of which provide a coherent and rational basis for a system of claimants' remedies. Finally, it concludes that, if the third-party claimant is to have recourse to the liability insurer, it should be under a consensual or statutory assignment rather than in his own right. Garnishment laws, consistently applied, might provide the simplest and most logical form of claimant relief with the least dislocation of the liability insurance system or of federal bankruptcy law.

\section{The Insured's Bad-Faith Suit}

\section{A. The Dimensions of the Suit}

The typical fact situation out of which an insured's bad-faith suit $^{1}$ against the insurer arises is aptly illustrated by Crisci $v$. Security Insurance $\mathrm{Co}^{2} \mathrm{Mrs}$. Crisci, the owner of an apartment building, had general liability coverage under a policy with Security against just such accidents as the one that occurred when Mrs. DiMare, a tenant in the building, fell through a stair tread. In the resulting lawsuit, the insurance company defended Mrs. Crisci, as its contract obliged it to do, and had exclusive control over all settlement negotiations, as its contract entitled it to do. The suit alleged physical, psychological, and other injuries and damages of $\$ 400,000$. Nonetheless, Mrs. DiMare and her husband first offered to settle for $\$ 10,000$, the limits of the policy, then for $\$ 9,000$ when Mrs. Crisci offered to contribute $\$ 2500$. Convinced that the physical injuries were worth no more than $\$ 3,000$ and that its experts could persuade a jury to disbelieve evidence of the psychological injuries, Security refused both offers. The company also knew, however, that a jury might award damages in excess of $\$ 100,000$ if it believed Mrs. DiMare's experts instead. The jury did just that, awarding the DiMares $\$ 101,000$ for their combined claims. After the company had paid the $\$ 10,000$ its policy required, Mrs. Crisci was left with a personal judgment of $\$ 91,000$ to satisfy. By the time

\footnotetext{
1 The designation "bad-faith suit" is employed throughout this comment for the cause of action that alleges insurer misconduct in refusing an opportunity to settle within policy limits. The standards against which insurer conduct is measured are actually much more varied than "bad faith." See text and notes at notes 20-26 infra.

266 Cal. 2d 425, 426 P.2d 173, 58 Cal. Rptr. 13 (1967) (en banc).
} 
she had done so, ${ }^{3}$ she was indigent, physically and mentally ill, and suicidal.

Under circumstances like these, insured parties like Mrs. Crisci would have a lawsuit against insurers like Security Insurance in almost any jurisdiction in the country. Whether the action sounds in contract ${ }^{5}$ or in tort, ${ }^{6}$ the company's conduct has harmed

s Mrs. DiMare took $\$ 22,000$ in cash, a $40 \%$ interest in a piece of property Mrs. Crisci owned, and an assignment of Mrs. Crisci's claim against Security, id. at 429, 426 P.2d at 176, 58 Cal. Rptr. at 16.

1 Rutter v. King, 57 Mich. App. 152, 158, 226 N.W.2d 79, 82 (1974). See generally Annot., 40 A.L.R.2d 168 (Later Case Supp. 1980). There apparently is no jurisdiction which denies the suit, although Mississippi requires a showing of insurer conduct that is virtual fraud, see Martin v. Travelers Indem. Co., 450 F.2d 542, 551 (5th Cir. 1971) (Mississippi law).

The availability of redress for insureds in Mrs. Crisci's position was not novel when the Crisci case was decided. Illustrative of early cases are: Brassil v. Maryland Cas. Co., 210 N.Y. 235, 104 N.E. 622 (1914): The insurance company refused a settlement offer of $\$ 1,500$ (the policy limit). Judgment was entered for $\$ 6,000$. The company also declined to handle an appeal and in effect tried to preclude one by refusing to pay its insured the policy limits until he had satisfied the judgment in full. The insured recovered his costs, including attorney's fees, for prosecuting an appeal. Excess liability was not an issue, because the original judgment for the claimant was reversed and the claimant did not bring his suit a second time. The New York Court of Appeals found that the company had violated "a contractual obligation of universal force which underlies all written agreements . . the obligation of good faith in carrying out what is written." Id. at 241, 104 N.E. at 624.

Brown \& McCabe, Stevedores, Inc. v. London Guarantee \& Accident Co., 232 F. 298 (D. Or. 1915). The plaintiff carried a liability policy, covering injuries to its employees, with the defendant company. The policy limits were $\$ 5,000$; the victim offered to settle for $\$ 3,000$. The company refused unless the insured would contribute $\$ 1,500$; damages of $\$ 12,000$ were awarded at trial. The insured recovered the $\$ 7,000$ difference between the judgment and the $\$ 5,000$ which the company ultimately paid out.

Hilker v. Western Auto. Ins. Co., 204 Wis. 1, 231 N.W. 257 (1930). The insurance company offered to settle a serious injury claim against its insured for $\$ 1,500$, adamantly refusing, despite policy limits of $\$ 5,000$, to raise its offer to the $\$ 2,500$ or $\$ 3,000$ the plaintiff was willing to accept. It also conducted only a cursory investigation into the accident out of which the lawsuit arose. The court applied agency law to hold against the insurer: the control of defense and settlement negotiations made the company the insured's agent, and the manner in which it conducted its agency violated its duties to its principal. Agency law is not, in fact, an appropriate analogy, because the insured cannot be considered a principal where the decision to accept or reject settlement offers is not his, but the insurer's, to make. R. Keeton, Basic Text on Insurance Law $\$ 7.10$ (b) (1971).

s The contract action is based on breach of an implied covenant of good faith and fair dealing: "that neither party will do anything which will injure the right of the other to receive the benefits of the agreement." Comunale v. Traders \& Gen. Ins. Co., 50 Cal. 2d 654, 658, 328 P.2d 198, 200 (1958). See also Brassil v. Maryland Cas. Co., 210 N.Y. 235, 241, 104 N.E. 622,624 (1914).

- The tort action arises because the company, by insisting on controlling the defense of its insured and any settlement negotiations that will bind it to pay, has undertaken a duty to the insured that is breached. See, e.g., Keeton, Liability Insurance and Responsibility for Settlement, 67 HARv. L. REv. 1136, 1138 (1954). Keeton indicates that tort rather than contract is the prevalent theory. Id. at 1138 n.5. 
the insured. If he sues after having paid the judgment, his damages are the difference between the policy limits and the judgment, ${ }^{7}$ supplemented by damages, if any, for physical harm, emotional distress, and causally connected financial injuries. In the egregious case, he can recover punitive damages. ${ }^{8}$

As a practical matter, however, the insured may not be able to pay the judgment before suing the insurer. The rule that an insured cannot demonstrate injury until he has paid all or part of the judgment generally has been abandoned. ${ }^{9}$ His second choice then is to sue the insured first and use the proceeds of the suit to pay the outstanding judgment debt. ${ }^{10}$ Again, he may be able to recover damages in addition to the excess liability, although his consequential injuries are apt to be less than they would have been had he paid the judgment. ${ }^{11}$

Third, instead of prosecuting the claim against the insurance company himself, the insured can assign it to the judgment creditor. The ability to assign is an important bargaining tool for the insured. Like the prepayment rule, the nonassignability of a bad-

${ }^{7}$ Moutsopoulos v. American Mut. Ins. Co., 607 F.2d 1185, 1188 (7th Cir. 1979) (Wisconsin law). See also notes 9, 16-19 infra.

3 For punitive damages under a contract theory, see Restatement (Second) of ConTRACTs $\$ 369$ (Tent. Draft No. 14, 1979): "Punitive damages are not recoverable for a breach of contract unless the conduct constituting the breach is also a tort for which punitive damages are recoverable." Punitive damages under a tort theory are awarded where the tortious conduct is fraudulent, malicious, oppressive, wanton, or reckless. See W. Prosser, HandBOOK OF THE LAW OF TORTS § 2, at 9-14 (4th ed. 1971).

- Maguire v. Allstate Ins. Co., 341 F. Supp. 866 (D. Del. 1972) (Delaware law) (to give force to change from insurance against loss to insurance against liability); Jessen $v$. O'Daniel, 210 F. Supp. 317 (D. Mont. 1962) (Montana law) (to allow same treatment as is accorded to medical expenses in a personal injury suit, where incurring obligation is suffcient), aff'd sub nom. National Farmers Union Prop. \& Cas. Co. v. O'Daniel, 329 F.2d 60 (9th Cir. 1964); Wolfberg v. Prudence Mut. Cas. Co., 98 Ill. App. 2d 190, 240 N.E.2d 176 (1968) (to discourage insurers from acting irresponsibly toward poor, judgment-proof, or dead insureds); Hernandez v. Great Am. Ins. Co., 464 S.W.2d 91 (Tex. 1971) (to relieve insureds from harm to credit standing and from sudden execution on and forced sale of leviable property); Schwartz v. Norwich Union Indem. Co., 212 Wis. 593, 250 N.W. 446 (1933) (to prevent injustice of making insured pay judgment that arguably is wrongfully imposed).

10 There is some concern that the insured will dissipate the proceeds of his suit before paying the judgment creditor. See Jones v. National Emblem Ins. Co., 436 F. Supp. 1119, 1122 (E.D. Mich. 1977) (Michigan law). Having the insured pay the proceeds into an escrow account or into the court registry, see Andrews v. Central Sur. Ins. Co., 271 F. Supp. 814 (D.S.C. 1967), aff'd mem. sub nom. Andrews v. Commercial Union Ins. Co., 391 F.2d 935 (4th Cir. 1968) (South Carolina law), should solve the problem.

11 In the absence of a prepayment rule, the insured can bring suit on entry of the judgment. Additional damages are as likely to arise from the insured's own delay and failure to mitigate as from the insured's conduct. 
faith claim is now rarely, if ever, asserted, whether the underlying theory of the suit is breach of contract or tort. ${ }^{12}$ The recovery on an assigned claim is limited to the excess liability, however. Damages for injury to the insured's physical and mental health, and punitive damages, can be obtained only by the insured. ${ }^{13}$

12 It was, however, a live issue as recently as 1967. See Note, Insurer's Liability to Judgment Creditor of Insured for Wrongful Refusal to Settle a Claim, 52 CoRnell L.Q. 778 (1967). See also Annot., 12 A.L.R.3d 1158 (Supp. 1979).

1s Where the theory of the bad-faith action is breach of contract, rights of action for damages are assignable. 4 A. Corbin, Corbin on Contracts $\S 886$, at 559 (1951). Where the underlying theory is tort, the situation is more complicated:

The following are the conclusions of a learned writer on this phase of assignability: "It is pretty generally held in America that the only causes or rights of action which are not transferable or assignable in any sense are those which are founded upon wrongs of a purely personal nature, such as slander, assault and battery, negligent personal injuries, criminal conversation, seduction, breach of marriage promise, malicious prosecution, and others of like nature. All other demands, claims and rights of action whatever are generally held to be transferable."

Id. at 560-61 (quoting 3 T. Street, Foundations of Legal Liability 86 (1906)).

4 A. Corbin, supra, § 886, at 52-53 (Supp. 1980), suggests that the general correlation between survivability and assignability has its origin in the idea that damages are a substitute for vengeance and an assuagement of personal violation. Kaufman, who prepared the 1980 Supplement, believes that, as damages are increasingly viewed as compensation for pecuniary loss, even personal injury damages may come to be assignable.

A further problem is the effect of a partial assignment. At law partial assignments were historically forbidden, because they subjected the debtor to the possibility of multiple suits. In equity, where the court had jurisdiction over the fund and where joinder rules were more flexible, partial assignments were permitted. With the fusion of law and equity, the better view is to allow partial assignment, leaving the debtor the option of insisting that all interested parties be joined. 4 A. Corbin, supra $\$ 889$, at 568-76 (1951), see Restatement (SEcoND) of Contracts $\S 158$, at $360-62$ (Tent. Drafts Nos. 1-7, rev. ed. 1973). Compare Purcell v. Colonial Ins. Co., 20 Cal. App. 3d 807, 97 Cal. Rptr. 874 (1971) (insured could not assign claim against insurance company, then bring own suit for personal damages) with Cain v. State Farm Mut. Auto. Ins. Co., 47 Cal. App. 3d 783, 121 Cal. Rptr. 200 (1975) (where assignment reserved insured's claim for physical injuries and mental distress, and where judgment creditor's and insured's suits were joined, partial assignment allowed).

Sometimes the distinction between assignable and nonassignable elements of damages is overlooked. The Crisci case itself is a puzzling example. In addition to the $\$ 91,000$ for. excess liability, the court awarded $\$ 25,000$ for Mrs. Crisci's pain and suffering, either because the insurance contract belongs to that category of contracts the breach of which "directly concern[s] the comfort, happiness or personal esteem of one of the parties," $66 \mathrm{Cal} .2 \mathrm{~d}$ at 434,426 P.2d at 179,58 Cal. Rptr. at 19, or because mental distress is a compensable element in tort, parasitic on the injury to property and physical health, id. at $433-34,426$ P.2d at 178-79, 58 Cal. Rptr. at 18-19. Mrs. Crisci evidently had assigned her whole claim to Mrs. DiMare, however, see note 3 supra. The court nowhere says whether it is overcompensating Mrs. DiMare, treating the assignment as a nullity, or (contrary to California practice at the time) allowing Mrs. Crisci to split her cause of action. 


\section{B. The Necessity for the Suit}

Some form of legal remedy is required to compensate insured parties and to deter insurers in situations like the one presented in Crisci. Despite its many ambiguities, the insured's bad-faith suit seems to be the most sensible solution. ${ }^{14}$ It occupies a position midway between pure freedom of contract on the one hand and strict liability on the other. It thus recognizes the reality that most liability insurance is purchased by parties who cannot be expected to understand all its ramifications and protect themselves against the conflicts of interest that arise in the settlement situation. It also recognizes that insurers are not being compensated sufficiently for courts to imply an undertaking to pay all claims within policy limits. The standard to which the insurance company is held is that it should use its investigative expertise and its litigation experience to assess the risk of liability. Having evaluated the risk, the company must also allocate it fairly between itself and the policyholder. ${ }^{15}$

The use of the excess judgment as the basic measure of damages also seems sensible. Two other measures have been suggested: a liquidated amount that is a function of the policy limits, ${ }^{16}$ or the value of the insured's leviable assets. ${ }^{17}$ Neither is an improvement.

14 Contra, Keeton, supra note 6, at 1183-86. See also Schwartz, Statutory Strict Liability for an Insurer's Failure to Settle: A Balanced Plan for an Unresolved Problem, 1975 DUKE L.J. 901.

1s Keeton, supra note 6, at $1145-46$, describes the insurer's duty to give equal weight to its own interests and the interests of its insured, without regard to such extrinsic factors as policy limits, the wealth or poverty of the insured, or the company's vulnerability to future claims. Equal consideration of both parties' interests "is . . . more consistent than . . . other standards with fair treatment of both parties-parties who have voluntarily entered into a relationship that gives rise to this conflict of interests, by a contract which does not specify that one interest or the other should prevail." Id. at 1146. The Keeton test ought to eliminate the insurer's willingness to gamble where a settlement offer is within policy limits; it should also prevent courts from concluding that any settlement offer within policy limits is presumed reasonable. It has not had the latter effect. See Johansen v. California State Auto. Ass'n Inter-Ins. Bureau, 15 Cal. 3d 9, 538 P.2d 744, 123 Cal. Rptr. 288 (1975).

${ }^{18}$ Keeton, supra note 6, at 1183-84. Statutory liquidated damages are widely used in the first-party bad-faith situation, see note 73 infra. In that situation no judgment in favor of a third party intervenes, however.

17 Schwartz, supra note 14, at 913-14, 917-18. The suggestion is taken from R. KEETON, supra note $4, \S 7.8(\mathrm{f})$. It is assumed here that the excess judgment is the better measurement so long as the insured may have to pay it or so long as the claim is, in the hands of the bankruptcy trustee, a means of redressing harm to the bankrupt's estate for the benefit of the general creditors of the bankrupt. See text and notes at notes 41-45 infra. The more difficult question is whether the claimant, to whom an assignment has been made outside the preference period, can sue for the excess judgment after the insured has received a 
So long as the insurer's wrongful conduct has caused the insured to owe an excess judgment, liquidated damages either undercompensate or overcompensate for that harm. Using the value of the insured's leviable assets invites insurers to be more cavalier in their treatment of poor policyholders than of rich ones. ${ }^{18}$ It also presents difficult timing problems if the judgment creditor delays execution or uses available procedures to keep the judgment alive, ${ }^{19}$ in the hopes that the insured will acquire the assets with which to satisfy it.

\section{Problems Inherent in the Suit}

Although the insured's cause of action is necessary to compensate for and to deter insurer overreaching, a number of practical problems remain in its application despite sixty years of case law development. ${ }^{20}$ What standard of conduct should subject the company to damages: bad faith, negligence, ${ }^{21}$ or some other standard? ${ }^{22}$ Must there be a settlement offer by the injured person before the company's duty to accept it can arise, ${ }^{23}$ or must the company take affirmative steps to initiate settlement? ${ }^{24}$ May the company wait

bankruptcy discharge. It seems that the rarity of such a chain of events, and the impossibility of measuring the insured's damages any other way, militate against refinements of the rule.

18 This concern is expressed in cases that abandoned the prepayment rule, see note 9 supra.

1. See note 105 infra.

20 The development and the ambiguities are discussed in Keeton, supra note 6. See also note 4 supra.

21 "The standards themselves [bad faith and negligence] are less different than they might seem since virtually the same evidence will be relied on to prove breach of duty, and the general reaction of the jury to a particular case is likely to be the same under either standard." R. KeEToN, supra note 4, § 7.8(b), at 510. Accord, Miller, Living with Bad Faith, 46 Ins. Counser J. 34, 34 (1979).

22 No jurisdiction has yet adopted strict liability. The Crisci court did advert favorably to an amicus brief that urged such a course on it, 66 Cal. $2 \mathrm{~d}$ at $430-31,426 \mathrm{P} .2 \mathrm{~d}$ at 177,58 Cal. Rptr. at 17. See also Rova Farms Resort, Inc. v. Investors Ins. Co., 65 N.J. 474, 323 A.2d 495 (1974) (dictum).

${ }^{23}$ E.g., Baton v. Transamerica Ins. Co., 584 F.2d 907 (9th Cir. 1978) (Oregon law).

24 Alt v. American Family Mut. Ins. Co., 71 Wis. 2d 340, 350, 237 N.W.2d 706, 713 (1976), has language that suggests such a duty, but the holding is narrower:

[I]n all cases involving a probable overage, an insurance carrier must be circumspect in respect to all settlement overtures which are not patently frivolous, whether they be legally binding offers or not, at least in situations where it would be apparent to a reasonable insurer that excess liability was probable and liability almost certain.

Id. at 353,237 N.W.2d at 714 . The insurance company had been relying on the technical defense that settlement offers had not been approved by the minor victim's guardian ad litem. 
until litigation begins, or can it be liable for failing to settle earlier $?^{25}$ Who has the burden of proof on the issue of company misconduct: the insured to prove negligence or bad faith, or the insurer to prove absence of fault? ${ }^{28}$

Even with the definitional problems resolved, other difficulties remain. The first is that the abuses the insured's suit is meant to correct are much more anomalous and infrequent than the case law might suggest. An insurer normally will settle a claim whenever the anticipated recovery and the cost of defending a lawsuit exceed policy limits; given the high costs of litigation, ${ }^{27}$ the effect of the calculation is to make settlement economically preferable in all but extraordinary cases. ${ }^{28}$ The insured's bad-faith suit should therefore be approached as a priori unlikely, and a strong factual showing should be required to warrant recovery.

A careful scrutiny of the fact situations in alleged bad-faith cases would have the additional advantage of minimizing opportunities for strategic behavior. Currently the victim of a tort can send what is known in the trade as the "plaintiff's bad-faith letter."2o The letter offers to settle his claim, either for a specified amount or for all the insurance coverage available, and gives the insurer a deadline for accepting the offer. If the offer is refused, the preliminary elements of a subsequent bad-faith action are in place.

${ }^{25}$ In the typical bad-faith suit, the company's timing may be a factor in evaluating its conduct, Knobloch v. Royal Globe Ins. Co., 38 N.Y.2d 471, 344 N.E.2d 364, 381 N.Y.S.2d 433 (1976), but there can be no liability to the insured unless a judgment in excess of policy limits has been awarded against him. The question becomes more difficult if the injured party can sue the insurance company directly, alleging his own injury rather than the insured's. See note 91 infra.

${ }^{28}$ The burden of proof depends on the nature of the insurer's conduct upon which the claim of bad faith is based. When the insured alleges misconduct other than a failure to accept an offer of settlement, the burden is on the insurer to disprove the allegation. Absent such an allegation, the burden is on the plaintiff to show that there was a firm offer of settlement within policy limits made to the insurer and that its failure to accept the offer was unreasonable. Baton v. Transamerica Ins. Co., 584 F.2d 907, 913 (9th Cir. 1978) (Oregon law).

${ }^{27}$ The company hires outside counsel to defend the action, rather than using house counsel, to avoid problems with Canon 5 and Canon 9 of the Code of Professional Responsibility. It may additionally have to furnish a separate lawyer for the insured, under Canon 4, if it appears that there is an actual conflict over whether to settle a claim or not.

${ }^{28}$ A study reported in 1 All-Industry Research Advisory Committee, Automobile InJuRIes AND TheIr CoMpensation in The UNITED States 14 (1979) indicated that, in the period covered by the survey, $20 \%$ of all bodily injury claims produced lawsuits, $1.5 \%$ went to trial, and $0.9 \%$ went to judgment.

29 The strategy is illustrated in Baton v. Transamerica Ins. Co., 584 F.2d 907 (9th Cir. 1978) (Oregon law). Insurance company attorneys are counseled to expect it routinely. See Miller, supra note 21, at 38. 
Furthermore, the bad-faith suit may well create more deterrence than is desirable. The prospect of such a suit is so unattractive to an insurer that it is likely to settle when it could win on the merits. The insured's discovery process-how did the company investigate the claim, what did the adjusters decide, what did the inhouse attorneys advise, how did trial counsel evaluate the chances of success-can paralyze the operations of a company's office. The cost of defending the suit is high. Moreover, a jury asked to find in favor of an individual insured and against a wealthy insurance company is apt to be swayed by the depth of the respective pockets.

How might the insurance industry respond to the pressures generated by bad-faith liability? ${ }^{30}$ To the extent that it can identify certain practices as "overreaching," it will eschew them. ${ }^{31}$ To the extent that it cannot identify in advance those practices that a court may characterize as bad faith, it will tend to settle more tort claims against insureds. Given the already high percentage of settled claims, however, it is not clear that additional incentives to settle are necessary. ${ }^{32}$ At the same time, because bad-faith liability can arise only if the insurer could have settled at or below policy limits, companies can be expected to write policies that reduce their exposure to bad-faith liability, if the scheme of regulations to which they are subject leaves them that choice. Such policies could have extremely high limits or extremely low limits. If the limits are high or nonexistent, the insurer can charge correspondingly large premiums. It can guarantee itself compensation for assuming the entire risk of its insured's liability, a risk that bad-faith liability now imposes on it for a much smaller premium payment. The difficulty is that many consumers who carry insurance would be unable to buy it at the higher premiums, and no one likes to contemplate an increase in the number of uninsured tortfeasors. If, on the other hand, policy limits are low, the insurer can routinely settle all claims within those limits and preclude bad-faith liability. Again the consequences are disturbing: systematic underinsurance avoids the insurer's problems only at a cost of inadequate protection

so What follows is entirely speculative. Insurance companies do not maintain files that indicate when their claims adjustment practices are influenced by threatened bad-faith liability. Judgments awarded for bad faith are trivial compared to the premium pool, but their effect on future settlements is nonetheless pervasive.

31 Thus Miller, supra note 21 , at $36-39$, gives a decalogue for insurers.

s2 See note 28 supra. 
against liability for the insured and inadequate compensation for those injured in person or property by the insured's conduct.

All these considerations suggest that there are paradigmatic situations, such as Mrs. Crisci's, where the equities strongly favor the insured's having a bad-faith action against the insurer. ${ }^{33}$ Likewise, the equities favor the action in its present form, with the excess judgment as the basic measure of liability even if the insured is not able to pay the judgment, ${ }^{34}$ and with special items of damage if the bad faith of the insurer is the proximate cause thereof. ${ }^{35}$ Nonetheless, bad-faith liability must be strictly construed. A court must satisfy itself that there was a genuine opportunity for settlement, ${ }^{36}$ that the insurer in refusing it created an unjustified risk that he should have foreseen, ${ }^{37}$ and that the insured did not do anything to cause his own harm. ${ }^{38}$ Because bad-faith liability carries with it the seeds of broad dislocations in the private liability insurance system, there is always the danger that a less rigorous approach, in the name of consumer protection or accident compensation, may benefit neither consumers nor accident victims.

\section{The Third-Party Bad-Faith Suit In Theory}

Ordinarily, if the bad-faith mechanism works to compensate the insured, it will also compensate the injured person to whom the insured is liable. The insured may prosecute his own bad-faith suit and use the damages to satisfy the outstanding judgment, or the insured and the claimant may strike a bargain whereby the claimant takes an assignment of the insured's suit in exchange for a covenant not to execute on the judgment.

Where there is no assignment, however, the claimant in most jurisdictions is remitted to the remedies he would have had against an uninsured judgment debtor. Under traditional contract law, unless the claimant can stand in the insured's shoes, he is a stranger

ss See text and notes at notes 14-19 supra.

34 See text and notes at notes 9, 16-19 supra.

ss See text and notes at notes 7-8 supra.

so Baton v. Transamerica Ins. Co., 584 F.2d 907 (9th Cir. 1978) (Oregon law).

s7 See Trask v. Iowa Kemper Mut. Ins. Co., 248 N.W.2d 97 (Iowa 1976), and cases discussed therein.

ss This factor should have received more attention in Cain v. State Farm Mut. Auto. Ins. Co., 47 Cal. App. 3d 783, 121 Cal. Rptr. 200 (1975) (insured gave conflicting accounts of accident); Boston Old Colony Ins. Co. v. Gutierrez, 360 So. 2d 464 (Fla. App. 1978) (insured did not want settlement, because he had filed a counterclaim against tort plaintiff; company did offer policy limits once counterclaim abandoned). 
to the relationship between insurance company and insured. Under traditional tort law, the company owes the claimant no independent duty to accept his settlement offer. According to traditional notions of causation, even if a contractual relationship or a duty could be inferred, the insurance company's conduct has caused the claimant no harm. In order for the issue of excess liability to arise at all, the claimant must have been willing to accept a settlement at or below policy limits. At the conclusion of the litigation he has received those limits and the personal judgment against the insured besides. ${ }^{39}$ In short, the compensation that the claimant can recover as assignee is his because of the contract of assignment; the funds he can obtain as judgment creditor come to him by ordinary processes of execution. He is not directly entitled to anything from the insurance company beyond the payment of policy limits.

The claimant for whom the liability insurer is just out of reach disagrees with the traditional analysis. He maintains that his offer ought to have been accepted and that he has been put to the expense and strain of litigating it to judgment for a gain that is illusory. He thinks that his chances for compensation in full are too dependent on the unilateral choice of the insured. ${ }^{40}$ But what he most dreads is that the imposition of the excess judgment on the insured will push the insured into bankruptcy. ${ }^{11}$ Once the insured files for bankruptcy, the judgment debt becomes simply another debt and the judgment creditor simply another creditor. He can only take his place in line with other creditors ${ }^{42}$ and watch while

39 These arguments are made forcefully by Keeton, supra note 6 , at $1175 \& \mathrm{n} .97$, and adopted by many courts, e.g., Murphy v. Allstate Ins. Co., 17 Cal. 2d 937, 553 P.2d 584, 132 Cal. Rptr. 424 (1976); Bennett v. Slater, 289 N.E.2d 144 (Ind. App. 1972).

10 The claimant's arguments are presented sympathetically in Jones v. National Emblem Ins. Co., 436 F. Supp. 1119, 1122 (E.D. Mich. 1977) (Michigan law).

11 The overriding aims of bankruptcy legislation are to give the debtor the opportunity to make a fresh start and to ensure the equitable distribution of assets to creditors. D. Epstein \& J. Landers, Debtors and Creditors 381-82 (1978). In most bankruptcies, if these ends are to be achieved, the judgment creditor's recovery must be adversely affected. The exception is the case where the judgment creditor is the sole creditor, e.g., Nichols v. United States Fidelity \& Guar. Co., 37 Wis. 2d 238, 155 N.W.2d 104 (1967).

The citations that follow will refer both to the Bankruptcy Reform Act of 1978, 11 U.S.C. $\$ \S 101-1330$ (Supp. II 1978) [hereinafter cited without cross-reference as Act of 1978], which applies to bankruptcy petitions filed after October 1, 1979, Act of $1978 \S 402$, 11 U.S.C. $\$ 402$ (Supp. II 1978), and to parallel provisions of the Bankruptcy Act of 1898, ch. 541,30 Stat. 544 (found as amended at 11 U.S.C. $\$ \S 1-1103$ (1976)) [hereinafter cited without cross-reference as Act of 1898], which was superseded by the Act of 1978 .

12 The bankrupt's creditors are divided into two groups, priority and nonpriority. Separate from both are secured creditors; the property in which they hold security interests is segregated for them and does not become part of the bankruptcy estate. Act of 1978 
the cause of action for excess liability, if it is colorable at all, is exercised or sold by the bankruptcy trustee for the benefit of the bankruptcy estate, rather than reserved to him. ${ }^{43}$ Furthermore, at the conclusion of the bankruptcy proceedings, the bankrupt's unpaid debts-including the judgment debt-are discharged.44 The

§ 541(b), 11 U.S.C. § 541(b) (Supp. II 1978); Act of 1898 § 70 (a) (found as amended at 11 U.S.C. \& 110(a) (1976)). See J. Trost, G. Treisler, L. Forman, K. KLee \& R. Levin, The New Federal Bankruptcy Code 175 (1979). The unsecured creditors' claims are proved, ranked into categories, then paid pro rata from the assets of the bankruptcy estate.

The judgment creditor's position among creditors of the bankrupt is not enviable. Under the new act, any lien he may have acquired on the debtor's property by virtue of having a judgment against the debtor is a "judicial lien," Act of 1978 \& 101(27), 11 U.S.C. $\S 101(27)$ (Supp. II 1978), avoidable if it has arisen within three months of bankruptcy, id. \$ 547. Any assignment or payment he has received in the same period is similarly undone, id. § 101(40); id. § 547. One of the major substantive differences between the new act and its predecessor is the treatment of preferences: under the old act, transfers within four months of bankruptcy could be avoided if the trustee could show that the creditor had reasonable grounds to believe that the debtor was insolvent when he accepted the transfer, Act of 1898 $\S 60$ (found as amended at 11 U.S.C. \$ 96 (1976)). Under the new act there is a presumption of insolvency in the three months before bankruptcy, and preferences are therefore easier for the trustee to prove and invalidate, Act of 1978 § 547(f), 11 U.S.C. § 547(f) (Supp. II 1978). The effect of these provisions on the judgment creditor is that his judgment will be of little use to him if there are other creditors; further, he cannot improve his position by taking an assignment-a result that may seem harsh as to him but is consonant with the bankruptcy law's aim of treating all creditors of the same category equally.

ts The insured's cause of action against the insurer for the excess judgment and other economic damage vests in the bankruptcy trustee as an inchoate property right, see Act of 1978 § 541, 11 U.S.C. § 541 (Supp. II 1978); Act of 1898 § 70(a)(5)-(6) (found as amended at 11 U.S.C. $\S 110(a)(5)$ \& (6) (1976)). See also J. Trost, G. Triesler, L. Forman, K. KLEE \& R. LEVIN, supra note 42 , at 95 .

The result of vesting is in keeping with one of the policies behind sec. 70(a)(5) of the Act, which seeks to secure for creditors everything of value the bankrupt may possess in alienable or leviable form when he files his petition, but avoids "coin[ing] into money for the profit of his creditors the bodily pain, mental anguish or outraged feelings of a bankrupt."

Nichols v. United States Fidelity \& Guar. Co., 37 Wis. 2d 238, 247, 155 N.W.2d 104, 109 (1967) (footnotes omitted).

If the trustee elects to bring the suit, the proceeds become part of the bankruptcy estate, paid out first to priority creditors, then to general creditors, class by class and pro rata. If the trustee elects not to bring the suit, the other creditors, who have no greater assurance of recovery from the bankrupt than the judgment creditor has, may compete to buy it. Act of $1978 \S 704,11$ U.S.C. $\$ 704$ (Supp. II 1978); Act of $1898 \S 70$ (f) (found as amended at 11 U.S.C. $\S 110(f)(1976))$.

14 Once the debts of the bankrupt have been paid from the available assets, in the order prescribed, Act of $1978 \S 507,510,726,11$ U.S.C. $\$ \S 507,510,726$ (Supp. II 1978), any debts remaining are discharged, so long as the bankrupt has not committed one of the bankruptcy crimes or had a bankruptcy discharge within six years, id. § 727(a); Act of 1898 § 14(c) (found as amended at 11 U.S.C. § 32(c) (1976)), and so long as the debt is not one of those enumerated as nondischargeable, Act of 1978 \& 523(a), 11 U.S.C. § 523(a) (Supp. II 1978); Act of 1898 \$17(a) (found as amended at 11 U.S.C. $\S 35(\mathrm{a})$ (1976)). In the context of judgment debts arising out of events that are covered by liability insurance, the only pos- 
discharge precludes any further efforts to collect on the judgment. ${ }^{45}$

It is not surprising, then, that the pressure for a direct thirdparty action against the liability insurer has been steady and unrelenting. To decide whether such an action should be allowed, one must weigh the suit's likely benefits to the claimant against the difficulties it poses for efficient and equitable administration of insurance law.

Theoretically, the third-party suit could take one of two forms. It could assert that the insurer's misconduct to the insured has harmed the claimant, or it could assert that the insurer has harmed the claimant directly. Whichever form it takes, it adds new problems to the basic difficulties already inherent in the insured's bad-faith suit. The most troubling of these involve calculating the measure of damages, avoiding a prejudicial impact on the jury if the suit goes to trial, and preventing a sharp increase in the costs of insurance. ${ }^{18}$

\section{A. The Measure of Damages}

When the insured sues the insurer for bad-faith refusal to settle, the injury is measurable by the excess judgment to which the insured would not have been exposed but for the insurer's misconduct. ${ }^{47}$ When the claimant brings a lawsuit alleging that the insurance company's bad-faith refusal to settle in the insured's interest has harmed him, should the same measure of damages apply?

sible exception to dischargeability would be judgments arising from "willful and malicious" injury to another entity or the property of another entity. Act of 1978 523(a)(6), 11 U.S.C. § 523(a)(6) (Supp. II 1978); Act of 1898 § 17(a)(8) (found as amended at 11 U.S.C. § 35(a)(8) (1976)). The draftsmen of the new act have been explicit about what that phrase means. "Under this paragraph 'wilfull' means deliberate or intentional. To the extent that Tinker v. Colwell, 139 U.S. 473 (1902), held that a looser standard is intended, and to the extent that other cases have relied on Tinker to apply a 'reckless disregard' standard, they are overruled." H.R. REp. No. 595, 95th Cong., 1st Sess. 365 (1977); S. REp. No. 989, 95th Cong., 2d Sess. 79 (1978). Because liability policies exempt deliberate wrongdoing from their coverage, the typical judgment against an insured defendant cannot be nondischargeable on this ground.

45 Act of 1978 § 524(a)(2)-(3), 11 U.S.C. § 524(a)(2)-(3) (Supp. II 1978); Act of 1898 § 14(f) (found as amended at 11 U.S.C. \& 32(f) (1976)).

16 The discussion throughout focuses on the simple paradigm of one insurer and one claimant. Where there are multiple claimants and problems of preferential settlement, or multiple insurers and problems of responsibility for settlement, the difficulties increase exponentially. See R. KeETON, supra note 4, \& 7.8(d), at 513-14.

47 See text and notes at notes 7, 9, 16-19 supra. Additional damages may also be available, see text and notes at notes 7-8 supra. 
Courts that deny the suit say no. They reason that the claimant's settlement offer represents the true value of his initial injury, and that any further harm caused by the insurance company is adequately compensated when he receives cash payment of the policy limits and the additional judgment against the insured.8 ${ }^{48}$ This argument ignores the possibility that the claimant's offer reflects, not the value of the injury, but the settlement value of the injury - that is, the value of the injury discounted by the costs of litigating the suit against the insured and by the possibility of losing. The claimant's argument, however, ignores that, had he asserted what he assumed was the true value of his injury initially, there might have been no possibility of settling within policy limits and hence no liability of the insurer for the excess judgment at all. How these factors should be balanced to arrive at a logical measure of damages is by no means clear, but treating the excess judgment as the proper measure cannot be analytically sound.98

If the gravamen of the claimant's suit is that the insurer owes him a duty to settle, ${ }^{50}$ then the existence of the excess judgment is irrelevant. The appropriate damages would be his attorney's fees, some dollar equivalent of the emotional distress of trial, and an interest penalty calculated on the amount for which he was willing to settle, for the time between the settlement offer and the entry of judgment. ${ }^{\text {s1 }}$ The insurer might also be liable for punitive damages. If not accepting a settlement offer creates a lawsuit in favor of the claimant, however, must not the insurer have the reverse suit, an action against the claimant who refuses an offer of settlement?

\section{B. Jury Prejudice}

In the ordinary personal injury or property damage case, rules governing discovery, evidence, and joinder have been designed to

48 See note 39 supra.

49 The opposite assumption is made in Crisci v. Security Ins. Co., 66 Cal. 2d 425, 431, 426 P.2d 173, 177, 58 Cal. Rptr. 13, 17 (1967):

The size of the judgment recovered in the personal injury action when it exceeds policy limits, although not conclusive, furnishes an inference that the value of the claim is the equivalent of the amount of the judgment and that acceptance of an offer within those limits was the most reasonable method of dealing with the claim.

so $T$ This assumption inheres in the suggested analogy to the first-party bad-faith claim, see text and notes at notes 68-74 infra, and in the discovery in the regulatory statutes of a duty to settle that runs to the claimant, see text and notes at notes 75-100 infra.

${ }^{81}$ This possibility is noted by Keeton, supra note 6, at $1175 \mathrm{n} .97$, although he points out that the stress of litigation, unlike the costs of litigation, is not a compensable harm under usual modes of analysis. 
meet the problem of jury prejudice arising from knowledge of insurance coverage. When the insured sues the insurer in a bad-faith suit, the jury has the additional and probably prejudicial knowledge of a judgment in excess of policy limits. The risk of prejudice is mitigated, however, by the absence of the injured party from the courtroom. In a claimant's direct bad-faith action, on the other hand, all the factors tending to create prejudice in favor of the plaintiff are in plain view of the jury. ${ }^{.2}$ It is therefore not surprising that juries sometimes find companies liable for staggeringly large excess judgments. ${ }^{53}$

\section{Increased Cost of Insurance}

If the direct action were simply the insured's action transferred to the claimant, the number of suits brought by insureds and their assignees would be augmented only by those suits, now prosecutable, that previously had been blocked because no assignment had been made. This would seem to create little risk of an increase in insurance premiums or a decrease in insurance coverage beyond the risk already inherent in the insured's bad-faith cause of action, ${ }^{54}$ provided that actions were policed to prevent double recoveries.

If the direct action were conceived of as involving a separate tort against the claimant, the increase in suits would probably be much larger, since both the insured and the claimant could sue for injuries arising out of a single instance of bad faith. There would undoubtedly be a corresponding increase in the number of settlement offers, ${ }^{\text {ss }}$ each of which would probably more closely approxi-

s2 In effect, the situation is like the first-party bad-faith suit against an insurer that has wrongfully delayed or withheld payment of benefits, see text and notes at notes 68-74 infra. Juries make large awards in these cases. See, e.g., Neal v. Farmers Ins. Exch., 21 Cal. 3d 910, 582 P.2d 980, 148 Cal. Rptr. 389 (1978) ( $\$ 15,000$ uninsured motorist coverage; award of damages of $\$ 1,548,211.35$ remitted to $\$ 749,011.48$, of which $\$ 9011.48$ was compensatory damages); Delos v. Farmers Ins. Group, 93 Cal. App. 3d 642, 155 Cal. Rptr. 843 (1979) (clear case of sharp insurance practices involving $\$ 10,500$ uninsured motorist coverage; jury awarded $\$ 10,500$ compensatory damages and $\$ 4,000,000$ punitive damages; remittitur to $\$ 350,000$ sustained).

ss E.g., Boston Old Colony Ins. Co. v. Gutierrez, 360 So. 2d 464 (Fla. App. 1978) (excess liability of $\$ 1,408,350.16$ on a policy with limits of $\$ 10,000$ ).

See text and notes at notes 20-38 supra.

ss The increased cost to insurers-and eventually to the purchasers of insurance-would be even greater if insurers chose to litigate rather than to settle. The jury, presented simultaneously with an injured plaintiff and knowledge of the insurer's refusal to settle, is likely to respond with an excessive verdict. See text and notes at notes 52-53 supra. 
mate policy limits. This increased cost to insurers would be passed on to those seeking insurance, making it more costly or less available.

To summarize, the third-party direct action creates problems beyond those involved in the insured's suit by making the calculation of damages less certain and by increasing the likelihood of jury prejudice. If the suit is conceived of as a tort directly against the claimant and is pursued in addition to the insured's suit, the problems of cost and equitable distribution of insurance proceeds are doubled.

\section{Judicial Attempts to Create the Third-Party Bad-Faith SuIT}

Despite the problems of the direct third-party suit, courts and commentators sympathetic to the claimant with an uncollectible judgment have been increasingly willing to provide the claimant with a direct means of recovery. The theories they have relied on to support this extension of insurer liability include third-party beneficiary theory, intentional tort theory, and negligence grounded in regulatory statutes. As will be shown, none of these efforts provide a coherent and persuasive resolution of the problem.

\section{A. Third-Party Beneficiary Theory}

The idea that parties enter into contracts of liability insurance intending that the amounts available under the policy will be paid to anyone injured by the insured is as old as the transformation of liability insurance from an indemnity contract to a more comprehensive form of protection. ${ }^{58}$ It is one of the rationales for direct-

se See, e.g., 4 A. CoRBin, supra note 13, § 807, at 213-16 (footnotes omitted):

[Liability and indemnity insurance] policies may be so worded as to make it clear that they are intended solely for the protection and indemnity of the insured. Indeed, the promise may be merely to reimburse the insured in case he is compelled to pay damages to some third party. If the contract is clearly for the sole benefit of the promisee, being merely for his indemnification or reimbursement, no third party has an enforceable right by virtue of the policy. There is a tendency, however, for the states to require by legislation the carrying of liability insurance for the protection of third parties. Policies that are issued by virtue of such legislation should be interpreted as being for the benefit of the injured third party and should be held to give him an enforceable right against the insurer. Even in the absence of such legislation the injured third party should have an enforceable right against the insurance company if the policy is so worded as to indicate that it was executed for the protection of third persons, or as to amount to a promise to pay the debt of the insured to the injured party. 
action statutes in those states that have them, ${ }^{87}$ and for compulsory automobile liability insurance and financial responsibility laws. ${ }^{58}$ The further idea that parties enter into contracts of liability insurance intending that injured parties be the beneficiaries of any amounts over policy limits that the insurer is forced to pay is much more difficult to accept. Only Florida has been willing to entertain it. $^{58}$

For the third-party claimant to be an intended, rather than an incidental, beneficiary, the liability insurance policy must contain actual or implied covenants that run to him. ${ }^{60}$ The terms of the

See also 8 J. Appleman, Insurance Law and Practice $§$ 4831, at 212-16 (1962 ed.).

s2 "[A]ll liability policies within their terms and limits are executed for the benefit of all injured persons, his or her survivors or heirs, to whom the insured is liable . . ." LA. Rev. Stat. Ann. § 22:655 (West 1978). See also P.R. Laws AnN. tit. 26, §§ 2001-2003 (Supp. 1976); Wis. Stat. ANN. \& 632.24 (West Supp. 1979); id. § 803.04(2) (West 1977). Arkansas and Rhode Island have limited direct action statutes. ARK. STAT. AnN. § 66-3240 (1976) (allowing direct action against an insurer when suit against insured is barred by immunity); R.I. GEN. LAwS § 27-7-2 (1971) (permitting joinder of insurer in action against tortfeasor when process cannot be served on tortfeasor).

Florida has a judicially created form of direct action based on third-party beneficiary doctrine, Shingleton v. Bussey, 223 So. 2d 713 (Fla. 1969). But see the statutory modification, Fla. Stat. Ann. § 627.7262 (West 1973).

New York, Minnesota, and New Hampshire (under limited circumstances) allow a tort plaintiff to attach the defendant's insurance policy to obtain quasi in rem jurisdiction. See Minichiello v. Rosenberg, 410 F.2d 106 (2d Cir.), cert. denied, 396 U.S. 844 (1969) (New York law); Seider v. Roth, 17 N.Y.2d 111, 216 N.E.2d 312, 269 N.Y.S.2d 99 (1966). The constitutionality of the Seider doctrine is open to question. See Rush v. Savchuck, 444 U.S. 320, 325-26, 330-33 (1980); Note, The Constitutionality of Seider v. Roth after Shaffer v. Heitner, 78 Colum. L. REv. 409 (1978).

See generally Smith, Direct Actions by Claimants against Liability Insurers, 27 FED'N INs. Counsel Q. 33 (1976).

sa See C. Gregory, H. Kalven \& R. Epstein, Cases and Materials in Torts 783-86 (3d ed. 1977) and authorities cited therein.

so Thompson v. Commercial Union Ins. Co., 250 So. $2 \mathrm{~d} 259$ (Fla. 1971). After his settlement offer had been refused, Thompson was awarded damages totalling $\$ 89,500$ against the insured, and Commercial Union paid its policy limits of $\$ 25,000$. Then, without benefit of assignment, Thompson sued Commercial Union for the balance. The Florida Supreme Court allowed the suit, reiterating its arguments in Shingleton v. Bussey, 223 So. 2d 713 (Fla. 1969). The Thompson result is not logically compelled by Shingleton, however.

Still later, Thompson appeared in court again. Thompson v. Commercial Union Ins. Co., 267 So. 2d 18 (Fla. App.), cert. denied, 271 So. 2d 461 (Fla. 1972). He had tried to use the garnishment procedure described in text and notes at notes 108-110 infra. True to its earlier opinion, the court refused to permit garnishment: as a third-party beneficiary, Thompson already possessed the rights of the insured, and the insured could not have garnisheed a potential debt to himself.

60 The following is an attempt at a consistent statement of the generally prevailing law: A third party who is not a promisee and who gave no consideration has an enforceable right by reason of a contract made by two others (1) if he is a creditor of the promisee or of some other person and the contract calls for a performance by the promisor in 
standard liability insurance contract ${ }^{61}$ support the following covenants: (1) to the claimant, to pay damages within the terms and limits of the policy, whether the claim is settled by an enforceable agreement or litigated to judgment; (2) to the insured, to conduct the investigation and defense of the claim and to excuse the insured from his obligation to pay, pursuant to settlement or judgment, within policy limits.

It is much more difficult to extract an inference from the policy language that the insurer and the insured, when they contracted, intended the claimant to be a third-party beneficiary beyond the policy limits. ${ }^{62}$ There are three possible arguments. The first is that, although the wrongful failure to settle is actionable by the insured because the company has violated a fiduciary duty owed to him, not to the party adverse to him, the insured intends to allow the claimant to assert his action. The problems in this argument are that no language suggests any such intent, and the actual conduct of insureds contradicts it. Insureds often bring their own suits, especially where there are personal damages as well as economic ones and the cause of action cannot be split. ${ }^{63}$ What is in effect a broad waiver of insureds' rights ought not to be created absent a clear intention to waive.

Second, it can be argued that wrongful failure to settle simply negates the language "within policy limits"; the insurance company cannot breach one part of the contract while maintaining the force of the favorable limitations of another part. It is as if a new policy came into existence at the moment of breach, and the only limitation on the amount of the new policy were the insured's legal obligation to pay. Under this analysis, however, the claimant is no longer the intended beneficiary of the new contract, but only the incidental beneficiary. There can be no common agreement about the claimant's rights in a contract that owes its existence to a disagreement about them.

satisfaction of the obligation; or (2) if the promised performance will be of pecuniary benefit to him and the contract is so expressed as to give the promisor reason to know that such benefit is contemplated by the promisee as one of the motivating causes of his making the contract.

4 A. Corbin, supra note $13, \S 776$, at 18 (footnotes omitted).

${ }^{61} \mathrm{R}$. KeETON, supra note 4, at 658.

62 Note that a different question is involved in asking whether the insured and the insurer were aware, when they contracted, that there were mechanisms by which a claimant could recover damages beyond policy limits.

os See text and note at note 13 supra. 
Third, one could argue that the parties intended from the outset that the third-party beneficiary, once he was identified, was to take advantage of more of the contract's covenants than the promise to pay within policy limits. Such a construction would make the claimant the direct beneficiary of the insurer's duty to settle. It would also make nonsense out of the policy because if the claimant can rely on more of the insurer's promises, he should owe more of the insured's duties. Yet no one argues that the insurer can impose, for example, the insured's duty of cooperation on the claimant. ${ }^{64}$

There is, in automobile liability insurance law, a person who does have this generous third-party beneficiary standing: the permissive user of the insured's automobile under the policy's omnibus clause. ${ }^{\circ 5}$ The omnibus insured's relation to the insurer is significantly different from that of the third-party claimant, however. Once the omnibus insured invokes the policy's coverage, he is bound by the terms of the policy; his relationship to the insurer is the same as that of the named insured..$^{68}$

One further argument in favor of third-party beneficiary theory rejects Corbin's approach-interpretation of the contract-and relies on "public policy" considerations. According to such an analysis, a state that makes automobile liability insurance mandatory or enacts a financial responsibility law does so to protect third parties. Insurance policies incorporate the statutory aim, making the claimant an intended beneficiary of any obligation of the insurer resulting from the policy. The response to this argument is that the insurer's bad-faith refusal to settle is not the harm that a mandatory-insurance statute is designed to avert. Public policy demands that insureds not be judgment-proof within certain limits,

\footnotetext{
See R. KEETon, supra note 4, at 655 .

"s The term "omnibus clause" is ordinarily used to signify a provision of a liability insurance policy designating additional insureds by an expansive class description in terms of some relationship to the insured. . . .

The most familiar use of omnibus clauses occurs in automobile liability insurance. The clauses used have been many and varied; virtually all, however, have had as a central theme that other persons driving the insured car with permission of the named insured are additional insureds.
}

... In the absence of some special relationship beyond that of permission to use the vehicle, [the omnibus insured] is ordinarily in the position of a donee beneficiary. Id. $\S 4.7(\mathrm{a})$, at 221-23.

ce Northwestern Mut. Ins. Co. v. Farmers Ins. Group, 76 Cal. App. 3d 1031, 1043-44, 143 Cal. Rptr. 415, 422 (1978). 
not that claimants be entitled to full satisfaction of all tort judgments. ${ }^{67}$

It is understandable, on the basis of the foregoing arguments, that the Florida experiment has not been imitated elsewhere. There seems to be no cogent theoretical objection to treating injured people as intended beneficiaries of the policy covenant to pay liability incurred by the insured within policy limits. Expanding third-party beneficiary rights to allow a direct suit in the excess liability situation is doctrinally difficult. More important, it alters the rights and duties of both original parties in unintended ways and changes the nature of private contract in an unsystematic and inchoate effort to achieve social ends.

\section{B. The Claimant's Direct Action Sounding in Tort}

An alternative approach is to abandon contract law altogether in favor of tort, and to seek to identify a wrong done by the insurer to the claimant qua claimant, not as representative of the insured, third-party beneficiary, or judgment creditor.

In its simplest form, the tort theory looks for an intentional wrong, ${ }^{68}$ for example, fraud, defamation, or intentional infliction of emotional distress (outrage). The main difficulty, however, is that insurance companies, however callous and aggressive, do not often commit such acts, especially in settlement negotiations or courtroom litigation where injured third parties are represented by attorneys. ${ }^{68}$ Even the most probable of these, the relatively new tort

${ }^{67}$ Compare Shingleton v. Bussey, 223 So. 2d 713, 716 (Fla. 1969) with Murphy v. Allstate Ins. Co., 17 Cal. 3d 937, 944, 553 P.2d 584, 589, 132 Cal. Rptr. 424, 429 (1976).

6 See Comment, Extending the Insurer's Duty of Good Faith and Fair Dealing to Third Parties under Liability Insurance Policies, 25 U.C.L.A. L. REv. 1413, 1435-36 (1978).

- Few liability insurance cases have been decided on this theory; of those that have, none involved excess liability. In Linscott v. State Farm Mut. Auto. Ins. Co., 368 A.2d 1161 (Me. 1977), the state supreme court denied the plaintiff's appeal from the dismissal of a suit alleging deceit, misrepresentation, economic duress, and negligent failure to settle. In Marsh v. General Adjustment Bureau, Inc., 22 Wash. App. 933, 592 P.2d 676 (1979), the claims adjuster represented to the plaintiff that it would take six months to a year to process her claim, but subsequently raised the statute of limitations as a defense. The appellate court affirmed summary judgment for the insurance company on the statutory and outrage counts, but remanded for consideration of equitable estoppel. In Bowe v. Eaton, 17 Wash. App. 840, 565 P.2d 826 (1977), the appellate court affirmed dismissal of the complaint, whether the plaintiff's theory was outrage, negligent infliction of emotional harm, or violation of a statutory duty.

Circumstances may be more conducive to such severe forms of insurer misconduct in the first-party situation, see text at note 69 infra. See also Holmes, Is There Life After Gilmore's Death of Contract?-Inductions from a Study of Commercial Good Faith in 
of outrage, requires the claimant to show that the company inflicted emotional distress intentionally or recklessly, that its behavior was outrageous in the extreme, and that the claimant's harm was caused by the company's behavior. ${ }^{70}$ Because the insured's tort is bound also to be a major factor in the claimant's harm, showing causation is an uphill battle. If the claimant can prove an intentional tort, however, no one, including insurance companies, would deny his right to recover. Under appropriate circumstances, recoveries could be substantial, especially if punitive damages were awarded. Absent some showing of collusion, however, one cannot justify under this theory the inclusion of a recovery from the insurance company of the excess personal judgment against the insured, simply because the personal judgment is uncollectible.

One commentator has taken the argument a step further. ${ }^{71}$ The intentional torts did not provide adequate remedies for insureds who were being denied benefits under their own policies of health, accident, and similar kinds of insurance. Hence it was necessary to create, for that situation, an analogue to the duty to settle-the duty to pay out benefits. It arose, like the duty to settle, from the covenant of good faith and fair dealing that California had long implied in all contracts. The "first-party" tort in California is now well established,,$^{72}$ and it has spread to other jurisdictions. $^{\text {.3 }}$ It is time for it to exert an influence on the third-party claimant's situation in the refusal-to-settle cases. Courts should be willing to find a comparable duty on liability insurers to settle claims, not because failure to settle harms the insured, but because injured claimants suffer from the same exigencies as insureds in the first-party situation. ${ }^{74}$

The argument glosses over an important distinction: the firstparty claimant is entitled to relief from the insurer not simply because his position is desperate, but because he has entered into contractual relations with the insurer and has paid a premium for

First-Party Insurance Contracts, 65 CoRnell L. REv. 331, 382-83 (1980).

70 The elements of the cause of action are set out in Marsh v. General Adjustment Bureau, Inc., 22 Wash. App. 933, 937, 592 P.2d 676, 679 (1979). The origins of the tort are described in W. Prosser, supra note 8, § 12.

71 Comment, supra note 68, at 1424-25, 1435-37.

72 The development is described and leading cases are cited in Holmes, supra note 69, at 355-67.

${ }^{73}$ The first-party suit for extra-contract damages is recognized in at least 21 states. Id. at 353-54. Seventeen of these have statutes that liquidate damages in the first-party situation, but the statutory penalty is not necessarily exclusive. Id. at $354 \mathrm{nn}$. 100-101.

7t Comment, supra note 68, at 1424-25. 
exactly the benefits he is now being denied. Those are conditions precedent to the insurer's duty to him. The third-party claimant has no such relationship to, and therefore no such claim on, a tortfeasor's liability insurer. The development of the first-party suit does not, by itself, support an analogous development in the third-party situation.

\section{Insurer's Negligence Based on Statute}

The desired result could be reached directly, however, by finding in the extensive state legislation regulating unfair claims settlement practices a generalized duty to settle claims, which runs to claimants as well as insureds, and an implied private right of action in addition to explicit administrative remedies.

Such legislation is fairly uniform, because state legislatures have enacted, more or less without change, model proposals of the National Association of Insurance Commissioners. ${ }^{75}$ The history of the NAIC proposals in Illinois may be taken as illustrative. ${ }^{78}$ In 1967 legislation ${ }^{27}$ authorized the insurance commissioner to investigate claims settlement practices and issue cease-and-desist orders or thirty-day license suspensions against insurance companies that "habitually and without just cause engage in a general business practice of unreasonable delay or refusing to settle claims." It defined such conduct as "unfair methods of competition and unfair and deceptive acts or practices in the business of insurance." 1971 additional legislation provided that "[n]ot attempting in good faith to effectuate prompt, fair, and equitable settlements of claims submitted in which liability has become reasonably clear" would constitute an improper claim settlement practice "if committed without just cause and performed with such frequency as to indicate a general business practice." "This provision was likewise to

${ }^{76}$ As of August 1979, 45 states had adopted versions of the NAIC Model Act Relating to Unfair Methods of Competition and Unfair and Deceptive Practices in the Business of Insurance; five (Hawaii, Oregon, Utah, Washington, and Wisconsin) had independent but similar provisions.

${ }^{76}$ It is recounted in detail in Scroggins v. Allstate Ins. Co., 74 Ill. App. 3d 1027, $1032-$ 35, 393 N.E.2d 718, 721-23 (1979).

77 Act of June 23, 1967, $1967 \mathrm{Ml}$. Laws 788 (repealed 1977).

78 Id. § 1031.

79 Act of Nov. 22, 1971, P.A. 77-1700, $1971 \mathrm{Ill}$. Laws 3248 (repealed 1977). The Illinois legislature here chose the language favored by the Industry Advisory Committee, representing the insurance companies, over the language of the commissioners' subcominittee. The latter had recommended "committing or performing with such frequency as to indicate a general business practice." 1 National Ass'N of Insurance Commisstoners, 1972 Proceed- 
be enforced by cease-and-desist orders and license suspensions.80 In 1977 the Illinois legislature substituted a new improper claims settlement practices section. It retained verbatim the 1971 language about "[n]ot attempting in good faith to . . . effectuate settlements." It also added a provision that such conduct would be considered a violation if "(a) It is committed knowingly in violation of this Act or any rules promulgated thereunder; or (b) It has been committed with such frequency to indicate a persistent tendency to engage in that type of conduct." ${ }^{\text {"22 }}$ The enforcement mechanism was not changed.83

These three pieces of legislation show several distinctive features. First, the scrutiny of company conduct has become more exacting: in 1967 a company had to be habitually and unjustifiably engaging in unreasonable delay; in 1977 a single knowing violation sufficed. Second, the implication of a private right of action for an individual claimant is precluded by the frequency requirement in the 1967 and 1971 versions. Whether the 1977 version's reference to a single knowing violation is meant to change that result is ambiguous. Third, the major role of insurance companies, both in drafting the model proposals and in lobbying state legislatures, ${ }^{84}$ suggests that the companies-and probably the legislators as well-expected no sudden alteration of liability insurance law to result. $^{.85}$

INGS 513 (1972).

Similarly, the industry representatives objected strongly to language that would have allowed the insurance commissioner to seek "such other relief as is reasonable and appropriate." They thought additional remedies were best left to a saving clause: "No order of the [Commissioner] under this Act or order of a court to enforce the same shall in any way relieve or absolve any person affected by such an order from any liability under any other laws of this state." Id. at 509. The committee that had initially supervised the drafting agreed to drop the offending provision in favor of the saving clause. Id. at 498, note.

so Act of Nov. 22, 1971, P.A. 77-1700, 1971 Ill. Laws 3248 (repealed 1977).

s1 Act of Sept. 22, 1977, P.A. 80-926, 1977 Ill. Laws 2714 (current version at ILL. REv. StAT. ch. 73, I 766.6 (1979)).

82 Id. (current version at ILL. Rev. Stat. ch. 73, I 766.5 (1979)).

ss Id. (current version at ILl. Rev. Stat. ch. 73, I 766.8 (1979)).

st See note 79 supra.

ss The industry's expectation is confirmed by a model regulation proposed to supplement the statutes. It discusses the insurers' duty to effectuate prompt, fair, and equitable settlements in two sections: one on insurers generally and one on automobile liability insurers in particular. Of the numerous strictures set out in it, only three relate to third-party claimants:

$8(e)$ the insurer must within 60 days notify a third-party claimant who does not have counsel that the applicable statute of limitations is running on his claim;

$8(f)$ the insurer must not tell a third-party claimant that his rights will be impaired by 
Given this general background, how have courts handled claimants' bad-faith suits that are based on the NAIC proposals as enacted, or on similar proposals? Washington appellate courts have rebuffed them. ${ }^{86}$ Washington's insurance regulation statute is part of its Consumer Protection Act. ${ }^{87}$ The courts therefore have read it as intended to protect buyers of goods and services, including buyers of insurance, and as inapplicable to parties who are extraneous to the consumer relationship.

Oregon and New York courts have held that NAIC-type legislation does not create a private right of action for the insured. . $^{88}$ Although the third-party claimant's case has not yet arisen, it is predictable that the courts would be even less inclined to find in the statutes a private right of action for noninsureds.

In March of 1979 the California Supreme Court reached the opposite result in Royal Globe Insurance Co. v. Superior Court. ${ }^{88}$ It interpreted the unfair claims settlement practices section of the California Insurance $\mathrm{Code}^{90}$ a modified version of the analogous

not filling out a form or signing a release within a certain time, unless the case falls within $8(\mathrm{e})$;

9(b) the automobile liability insurer must not recommend that third-party claimants make claims under their own policies solely to avoid paying claims under its insurance contract.

2 National Ass'n of Insurance Commissioners, 1976 Proceedings 369-70 (1976).

${ }^{86}$ Marsh v. General Adjustment Bureau, Inc., 22 Wash. App. 933, 936, 592 P.2d 676, 678-79 (1979); Bowe v. Eaton, 17 Wash. App. 840, 846, 565 P.2d 826, 830 (1977). See note 69 supra.

87 Wash. Rev. Code ANN. § 19.86 (1978).

8s An Oregon plaintiff sued his insurer for failure to defend him in a lawsuit, Farris v. United States Fidelity \& Guar. Co., 284 Or. 453, 587 P.2d 1015 (1978)—an ordinary contract action under Oregon law with damages limited to the costs of substitute counsel. Id. at 455, 587 P.2d at 1016. He wanted, however, to use the statutory settlement provision, Or. Rev. STAT. \& 746.230(1) (1979), to create a tort claim, with damages for emotional suffering and punitive damages. The Oregon Supreme Court found "nothing to indicate that the legislature intended, when it prohibited certain claims settlement practices . . . that actions for breach of insurance contracts would be transformed ... into tort actions with a resulting change in the measure of damages." 284 Or. at 458, 587 P.2d at 1018.

An intermediate New York court was even more explicit in a first-party suit alleging delay in paying benefits on a fire insurance policy and improper cancellation of the policy after payment. Cohen v. New York Property Ins. Underwriting Ass'n, 65 A.D.2d 71, 410 N.Y.S.2d 597 (1978). The trial judge had granted the defendant's motions for summary judgment on the plaintiff's additional claim for punitive damages, predicated on the statute, N.Y. INs. LAw \& 40d (McKinney Supp. 1979), and the appellate court affirmed. The statute "does not create a private right of action but rather affords a public right of redress by the Insurance Department for violations." 65 A.D.2d at 78-79, 410 N.Y.S.2d at 602 .

${ }^{82} 23$ Cal. 3d 880, 592 P.2d 329, 153 Cal. Rptr. 842 (1979).

${ }^{\circ}$ CAL. Ins. Code $\$ 790$ (West 1972). 
NAIC provision, as providing the claimant with a tort action against the insurer for its refusal to settle a claim once liability had become "reasonably clear."

Section $790.09^{92}$ of the California Insurance Code provides that " $[n]$ o order to cease and desist issued under this article ... shall in any way relieve or absolve such person from any . . . civil liability or criminal penalty under the laws of this State arising out of the methods, acts or practices found unfair or deceptive."9s The parallel NAIC provision provides that the violator is not absolved of liability arising under "any other laws" of a state. ${ }^{94}$ The majority found this distinction in the California statute sufficient to premise civil liability on section 790.09 itself. This premise was essential to its holding, because preexisting California law had precluded a direct action by a plaintiff in excess of policy limits. $.^{93} \mathrm{Jus}-$

21 $23 \mathrm{Cal}$. 3d at 884-85, 592 P.2d at $332,153 \mathrm{Cal}$. Rptr. at 845. If the court's interpretation-that the statute implies a private right of action-is correct, it is curious that nothing in the statute precludes a claimant from pressing his statutory suit before a final determination of liability. The options are either to preclude such a result by relying on something outside the statute to prevent the simultaneous determination of negligence and statutory liability, or to allow the statutory suit without established negligence liability. The former course was followed in Royal Globe. The plaintiff's suit was dismissed as premature because it sought to determine negligence and statutory liability at the same time by joining the insured and insurer as defendants. The court held that such a procedure was contrary to section 1155 of the Evidence Code, Cal. Evid. Code $\$ 1155$ (West 1966), and prejudicial to the insured's defense. Allowing the statutory suit before the determination of negligence liability would be absurd. See Linscott v. State Farm Mut. Auto. Ins. Co., 368 A.2d 1161, 1164 (Me. 1977): "[A]s the tort claimant has no legal right to require the tortfeasor to negotiate or settle, it likewise lacks right to require such action by his representative."

" CaI. INs. Code $\S 790.09$ (West 1972).

"Id. (emphasis added).

" See note 79 supra.

95 The most surprising feature of the majority opinion is the ease with which it distinguished the line of California cases, culminating in Murphy v. Allstate Co., 17 Cal. 3d 937, 553 P.2d 584, 132 Cal. Rptr. 424 (1976), that had held that a claimant who did not have an assignment from the insured could not sue the insurer for bad-faith refusal to settle. "Our holding," Justice Mosk wrote, "was based primarily upon contractual principles." Royal Globe Ins. Co. v. Superior Court, 23 Cal. 3d 880, 889, 592 P.2d 329, 335, 153 Cal. Rptr. 842, 848 (1979). The plaintiff in Murphy, suing for the wrongful death of her son, had collected the policy limits from Allstate, but had been unable to get an assignment of the insured's bad-faith claim. She therefore posed several statutory arguments. The first was that CAL. INs. CoDE $\$ 11580(\mathrm{~b})(2)$ (West 1972) provides that a judgment creditor can sue directly "on the policy and subject to its terms and limitations . . . to recover on the judgment." The court found that the provision only enabled the plaintiff to reach the insurance company for the policy limits, which had already been paid. Murphy v. Allstate Ins. Co., 17 Cal. 3d 937, 944, 553 P.2d 584, 588-89, 132 Cal. Rptr. 424, 428-29 (1976).

The plaintiff's second argument was that California's Financial Responsibility Law, CAL. VEH. CoDz $\S \S 16000-16560$ (West 1971), operates to enlarge the remedies of a claimant plaintiff under section $11580(b)(2)$ by refusing to let insurance companies use technical de- 
tice Mosk, writing for the court, noted that the legislators framing the provision had been made aware that the section might be construed to support a private third-party claim. Because they had failed to clarify their intent, Justice Mosk concluded that the omission of "other" in the provision was a deliberate departure from the NAIC position and from the prior course of California insurance law.

Justice Richardson, on the other hand, thought that the language was written only to preserve existing liability, and that the enforcement of the provisions themselves was to be purely administrative. ${ }^{98}$ His position is supported by the origin and legislative

linquencies of the insured to invalidate the policy as to injured-party claims. It sets a policy of full recovery which the court should regard. The court answered that technical delinquencies were not an issue in this case, and that no generalized intent to extend the remedies of section $11580(b)(2)$ beyond the policy terms and limits should be inferred from the treatment of technical delinquencies. $17 \mathrm{Cal}$. 3d at 944, $553 \mathrm{P} .2 \mathrm{~d}$ at 588, $132 \mathrm{Cal}$. Rptr. at 428. It also found that the aim of the Financial Responsibility Law was only that persons injured by negligent motorists be compensated to the extent of obligatory insurance, that Mrs. Murphy as administratrix had been so compensated, and that her direct action for the excess was not required to effectuate the law's purpose. Id.

The plaintiff's third argument was that CaL. Crv. Proc. Code $\$ 720$ (West 1980) describes circumstances under which a judgment creditor may reach property of a third party who is indebted to the judgment debtor by a garnishment proceeding. The court ruled that, even if the property damage elements of the insured's cause of action might be garnishable, because assignable, allowing garnishment would either split the insured's cause of action or prejudice the rights of the insured by permitting his action to be appropriated. $23 \mathrm{Cal} .3 \mathrm{~d}$ at 946, 553 P.2d at 590, 132 Cal. Rptr. at 430.

Murphy represents, therefore, not only a case in which a contractual cause of action was precluded by privity requirements, but also a determination that California statutes, before the enactment of section $790.03(\mathrm{~h})$ in 1972 , provided no direct private right of action for a bad-faith refusal to settle.

Royal Globe Ins. Co. v. Superior Court, 23 Cal. 3d 880, 892, 592 P.2d 329, 337, 153 Cal. Rptr. 842, 850 (1979) (Richardson, J., concurring and dissenting). The two opinions also differed as to whether liability could be premised on a single violation. Section 790.03 (b) provides that deceptive practices include "knowingly committing or performing with such frequency as to indicate a general business practice" a variety of acts, including failure to effectuate a settlement once liability is "reasonably clear." Justice Mosk read the "knowingly committing" and "performing with such frequency" language as wholly disjunctive. So long as Royal Globe "knowingly committed" one violation, it was liable to the claimant. Justice Richardson read the statute to require frequent violations, pointing out that it would be impossible to commit the proscribed practice without knowledge. The dissent thus highlighted the failure of the majority to define "knowledge" or to determine if it was present in the Royal Globe case. Justice Richardson also relied heavily on the practice of the Insurance Commissioner who had construed the statute to require a "general business practice" for liability to exist.

One interpretation of the statutory language is that the "knowledge" element was included to enable the Insurance Commissioner to issue a cease-and-desist order, and pursue other administrative remedies, for a single, particularly flagrant violation. A second interpretation is that the "knowledge" requirement was included to require scienter in every 
enactment of the NAIC proposals, ${ }^{97}$ by the interpretation of the state insurance commissioner, ${ }^{98}$ and by preexisting California law..$^{99}$ As he indicated, it is unlikely that the legislature would rely on the omission of one word-"other"- to alter the status quo. It is particularly doubtful, even if the majority's arguments were stronger, that the judicial interpretation of an ambiguous statute should prevail over the established interpretation of the administrative agency entrusted with its enforcement. The dissent has the better of the argument in Royal Globe. ${ }^{100}$

\section{A Cautionary Note on Judicial Activism}

The various attempts to find a claimant's direct bad-faith suit all involve judicial interpretations of common law principles or statutes not clearly designed to provide such a cause of action. Each of these attempts has been found unconvincing. Taken together, however, they are open to a further objection. Regardless of one's general feelings about judicial activism, the realm of insurance law is an exceptionally inappropriate area for judicial creativity. The insurance area is subject to complex and extensive regulation. In the field of automobile liability insurance, for example, financial responsibility laws dictate how much insurance drivers must carry; assigned risk pooling arrangements direct who must furnish it; statutes detail what the substantive policy provisions must be; no-fault schemes regulate how payments are to be made and when private suits are to be allowed. The laborious process by which such regulation is put into place involves extensive informa-

case, because national insurance companies were worried about keeping abreast of changes in state regulations.

27 Cal. 3d at 893-96, 592 P.2d at 338-40, 153 Cal. Rptr. at 851-53 (Richardson, J., concurring and dissenting).

os Id. at 897, 592 P.2d at 340, 153 Cal. Rptr. at 853 (Richardson, J., concurring and dissenting).

" Id. at 892-98, 896, 592 P.2d at 337, 340, 153 Cal. Rptr. at 850, 853 (Richardson, J., concurring and dissenting).

${ }^{100}$ Injured parties in Illinois were unsuccessful in their efforts to bring a Royal Globe suit; like the California plaintiff in Royal Globe, they had not yet become judgment creditors of the insured. The Illinois appellate court affirmed the dismissal of the insurer from the suit. It also examined in some detail the rationale of Royal Globe: apart from the difference in statutory language (Illinois retained "other," see text and notes at notes 79, 92-95 supra), the court emphasized the unanimity of California law through Murphy, the indirection with which the California legislature had acted if its intent was to create a duty "in derogation of so much common law," and the dangers in judicial usurpation of legislative functions. Scroggins v. Allstate Ins. Co., 74 Ill. App. 3d 1027, 1035-36, 393 N.E.2d 718, 724 (1979). 
tion gathering, lobbying by interest groups, accommodations, and political accountability. It can only be delayed and made more complex by unexpected judicial intervention. ${ }^{101}$

The same argument could of course be advanced against the insured's bad-faith suit, which is also judge-made. That action has developed over more than half a century, however, ${ }^{102}$ with the acquiescence of legislatures. It also originated in an era before complex regulation. Trying to turn back the clock under such circumstances would be quixotic. Not wanting to repeat the process, ${ }^{103}$ where all indications suggest that it will be even more confused and disruptive, is merely prudent.

\section{Garnishment by Claimants}

If the claimant's direct bad-faith action is rejected, as this comment has argued it should be, the claimant is once again in the position of being able to pursue the liability insurance company for amounts in excess of the policy limits only as the assignee of the insured. In one sense, this is a desirable state of affairs. It means that the insured's bad-faith suit, designed to protect insureds against a particular form of insurer misconduct, will not be unsystematically converted into a vehicle for correcting the defects in our system of tort compensation. It means that no new, difficult questions of duty, causation, or damage measurement need be added to the still unresolved questions in the insured's bad-faith suit, and perhaps also that some of the most persistent problems with the insured's suit may be addressed. It means, finally, that there is some possibility of predicting the consequences of bad-faith liability and correcting perverse incentives as they are identified, because the entire bad-faith area will no longer be changing more rapidly than these calculations can be made.

In another sense, however, allowing the insured's prosecution or assignment of the suit to be the claimant's sole remedy puts a premium on the insured's willingness or ability to cooperate. Whether the premium is too high depends on factors that can be

101 There seems to be no movement toward legislative enactment of the claimant's suit. Schwartz, supra note 14, at 917 , has proposed a model statute that has the coincidental effect of giving the claimant a direct action. Its main purpose, however, is to restructure the insured's bad-faith suit. See notes 14, 17 supra. With bad-faith liability thus restructured, the claimant's suit adds little or nothing to his traditional remedies.

103 See text and note at note 4 supra.

${ }^{103}$ A good deal of the confusion described in text and notes at notes 20-26 supra is the inevitable consequence of case-by-case adjudication and doctrinal adventurism. 
identified but not weighed without empirical study.

On the one hand, an insured who has a colorable bad-faith claim has a powerful self-interest in assigning or prosecuting it. Disappearing from the jurisdiction, for example, tolls the statute of limitations on the outstanding judgment. ${ }^{104}$ Intransigence lets the judgment loom over the insured so long as the judgment creditor keeps it alive. ${ }^{105}$ Conversely, an insured who has neither assigned nor prosecuted probably does not have a case against the insurer, and the claimant has lost nothing. If this description is accurate, then the claimant's problem is nonexistent, or his argument is a pretext. As noted earlier, the claimant's more serious worry is the insured's bankruptcy. ${ }^{106}$ Although compensation of accident victims is a major aim of both law and policy in the insurance field, that aim must yield when it comes into conflict with the purposes of bankruptcy law, which is designed to treat all creditors equitably and to permit the debtor to have a fresh start. ${ }^{107}$ These ends cannot be achieved without sacrificing the claims of individual creditors.

On the other hand, there may be situations where the insured does not behave as rational self-interest would dictate. Other factors-fear, illness, confusion, malice, pressure from the insurer-may be decisive. If this description is accurate, then what is needed is a method of forcing an assignment. Postjudgment garnishment $^{108}$ could be so used. It is a form of statutory assignment; ${ }^{109}$ its theory is that the putative liability of the insurance

104 What steps must be taken before the judgment creditor has a lien on the property of the judgment debtor is a matter of local law. The following, therefore, are only broad and rudimentary generalizations. For the tolling of the statute of limitations, see 49 C.J.S. Judgments $\S 496$, at 949-50 (1947) (absence of judgment debtor from the state).

${ }^{10 s}$ See id. § 532 (dormant judgments); id. §§ 533-549 (revival of judgments) (1947 \& Supp. 1980).

10 See text and notes at notes 41-45 supra.

107 See note 41 supra.

108 See 38 C.J.S. Garnishment § 16, at 220-222 (1943 \& Supp. 1980). There are two important consequences of allowing the judgment creditor to use postjudgment garnishment in this context: (1) the amount of the excess judgment is known, so that the insurance company's indebtedness, if it is found liable, is easily measured; (2) the judgment creditor can avail himself of garnishment procedures, not because he has a claim against the insurance company, but because he is entitled to seize the judgment debtor's assets, within the limits imposed by exemption and bankruptcy, to satisfy the judgment debt.

10s Shaw v. Botens, 403 F.2d 150, 153 (3d Cir. 1968) (Pennsylvania law); Gilley v. Farmer, 207 Kan. 536, 544, 485 P.2d 1284, 1290 (1971). Note that the problem presented by Thompson v. Commercial Union Ins. Co., 267 So. $2 \mathrm{~d} 18$ (Fla. App.), cert. denied, 271 So. 2d 461 (Fla. 1972), see note 59 supra, does not arise. The judgment creditor acquires the insured's rights by virtue of the garnishment proceeding, rather than having them first and 
company for bad-faith refusal to settle is a debt owed to the insured, that the debt is an asset to which the judgment creditor can lay claim, and that the issue of whether the liability exists, like the issue of whether an ordinary garnishee is truly indebted, can be resolved in the garnishment proceeding. ${ }^{110}$

From the claimant's point of view, garnishment would prevent the insured from causing him the initial harm and then taking a dog-in-the-manger attitude about compensating him for it. From the insured's point of view, garnishment, by postponing a compulsory assignment until execution on the judgment, would give him time to decide how he wants to proceed and to extract some negotiating benefit from the ability to make a voluntary assignment. From the systemic point of view, garnishment would increase the number of bad-faith suits somewhat, because it would allow claimants without voluntary assignments to raise the issue as garnishers, but it would not increase the scope of bad-faith liability, because it would continue to treat the claimant as if he were the insured. To the extent that garnishment proceedings do not involve trying issues before a jury, ${ }^{111}$ some jury findings based on sympathy for claimants and hostility to insurers may be avoided. It is not essential to the argument, however, that jury trials be precluded.

Garnishment has in fact been used in a few states $^{112}$ by judg-

being precluded from garnishment therefore.

Similar results are obtained by two less common methods. Iowa, Iowa Code AnN. § 516.1 (West 1949), and Connecticut, Conn. Gen. Stat. ANN. \& 38-175 (West 1969), have specially worded unsatisfied judgment acts that allow the judgment creditor to sue the insurer to the same extent the insured could have. Generally, unsatisfied judgment acts include the phrase "under the policy," which restricts the judgment creditor's recovery to policy limits; the Connecticut and Iowa statutes have been construed to give the judgment creditor the insured's excess liability suit as well. See Trask v. Iowa Kemper Mut. Ins. Co., 248 N.W.2d 97 (Iowa 1976). Under the second method, a few states have, as special proceedings supplementary to execution, the appointment of a statutory receiver who can pursue the bad-faith claim for the benefit of all the creditors of the insured. See Lange v. Fidelity \& Cas. Co., 290 Minn. 61, 185 N.W.2d 881 (1971); In re Kreloff, 65 Misc. 2d 692, 319 N.Y.S.2d 51 (Sup. Ct. 1971). Postjudgment garnishment seems preferable to either of these because all states have garnishment laws and thus there is a greater potential for uniform treatment.

${ }^{130}$ Rutter v. King, 57 Mich. App. 152, 169-71, 226 N.W.2d 79, 87-88 (1974).

11 Postjudgment garnishment is a statutory creation, with similarities to such equitable remedies as creditors' bills. It therefore is not triable to a jury unless the statute specifically so provides. 38 C.J.S. Garnishment \& 236 (1943 \& Supp. 1980). In the usual garnishment proceeding, however, the debt is not contested; in the use of garnishment proposed here, the existence of the debt is the main issue. It is fairer, therefore, if the state allows substance to prevail over form, and treats the proceeding as a juriable civil suit if either party so requests. Persuasive analogies can be found in Ross v. Bernhard, 396 U.S. 531 (1970), and Dairy Queen, Inc. v. Wood, 369 U.S. 469 (1962).

${ }_{112}$ Shaw v. Botens, 403 F.2d 150, 154 (3d Cir. 1968) (Pennsylvania law) (garnishable as 
ment creditors when the insured judgment debtor has a bad-faith claim. It is not more widely used because most garnishment statutes do not by their terms reach tort claims or unliquidated or contingent debts, ${ }^{113}$ and most states treat the insurer's bad-faith suit as sounding in tort. ${ }^{114}$ But that characterization is not inevitable: either breach of an implied contractual term ${ }^{115}$ or breach of the express covenant to defend ${ }^{116}$ would equally support the insured's suit against the insurer, and the measure of damages for contract breach or tort no longer varies significantly in this context. ${ }^{112}$ More particularly, the characterization of the insured's action in the garnishment context could easily be different, since the amount garnishable would be established by the excess judgment and no personal or other hard-to-measure damages would be involved.

The more difficult question is whether the bad-faith issue could practically be resolved in garnishment proceedings. As things

\footnotetext{
"definite and liquidated" claim, analogous to garnishable claim within policy limits where insurer denies coverage); Gilley v. Farmer, 207 Kan. 536, 485 P.2d 1284 (1971) (garnishable as a contract claim, whether liquidated or unliquidated); Rutter v. King, 57 Mich. App. 152, 226 N.W.2d 79 (1974) (garnishable as claim evidenced by a judgment).

${ }^{113}$ See note 112 supra. See also Powell v. Prudence Mut. Cas. Co., 88 Ill. App. 2d 343, 232 N.E.2d 155 (1967) (statute requires debt to be liquidated and not contingent). Courts sometimes add other reasons to reinforce their characterization of the action. See Linder v. Hawkeye-Security Ins. Co., 472 S.W.2d 412 (Mo. 1971) (where the legislature has regulated insurers extensively, a court should not intervene with novel constructions of garnishment statute), appeal dismissed, 405 U.S. 950 (1972); Pringle v. Robertson, 258 Or. 389, 465 P.2d 223 (1970) (garnishment would allow an outsider to meddle in the contractual rights of two parties); Paul v. Kirkendall, 6 Utah 2d 256, 311 P.2d 376 (1957) (the purpose of pretrial garnishment is to hold property pending the outcome of litigation, not to compel the garnishee to defend himself on a charge of wrongdoing).
}

In California, where the analogous creditor's bill exists as an equitable method of satisfying a judgment, the court in Murphy v. Allstate Ins. Co., 17 Cal. 3d 937, 945-46, 553 P.2d 584, 589-90, 132 Cal. Rptr. 424, 429-30 (1976), struggled to explain why, if tort claims for property damage could be subject to a creditor's bill, the insured's bad-faith claim, at least insofar as it was for excess liability, could not. The court concluded that the possibility that the insured might have other items of damage and might still want to pursue an unsplittable cause of action was enough to justify its result. See note 95 supra.

11 See note 6 supra.

115 See note 5 supra.

116 So characterized, it would have to be distinguished from the situation where the insurance company completely fails to defend, usually in the belief that the policy does not cover the occurrence that is the basis of the suit. The logical damages for failure to defend are the costs of a substitute defense procured by the insured himself; California, however, has enlarged the measure of damages to coincide with those available for bad-faith refusal to settle or to provide benefits, on the theory that the insurer who fails utterly to defend should not be in a better position than the insurer who defends inexpertly. See generally Farris v. United States Fidelity \& Guar. Co., 284 Or. 453, 458-65, 587 P.2d 1015, 1019-22 (1978).

11 See text and notes at notes 7-8 supra. 
now stand, finding bad-faith liability is in many cases a more complicated undertaking than the usual inquiries about whether a contract has been breached or a debt incurred by the ordinary garnishee. ${ }^{118}$ Nor should it be made to appear simple because of hindsight. ${ }^{119}$ It could be manageable, however, if the doctrinal elements of the insured's suit were defined more logically and handled more uniformly.

At first sight, there also appear to be problems about fairness to the insurance company: the proposal seems to advocate litigating a three-party issue between two parties. The problems are resolved, however, by bearing in mind that the claimant appears in two roles. He is the plaintiff in a garnishment action, where the insured would only be involved as much as any judgment debtor ever is. He is also the assignee of the insured's bad-faith suit, in which capacity he would fail to sustain his burden of proof, and lose, if the insured's conduct were material and the insured could not be brought into the proceedings. ${ }^{120}$

Finally, postjudgment garnishment gives the claimant a means of satisfying his judgment without pushing the insured into bankruptcy. It does not, however, permit the claimant to advance himself at the expense of the insured's other creditors if there is a bankruptcy. The new Bankruptcy Code's preference provisions ${ }^{121}$ operate to invalidate any transfer-a term of art that would include execution pursuant to garnishment as well as payment by the insured or assignment-within three months of the filing of a bankruptcy petition.

118 Contra, Rutter v. King, 57 Mich. App. 152, 171, 226 N.W.2d 79, 88 (1974), (likening garnishment of bad-faith liability to garnishment of wages or of damages within policy limits: "that the present garnishment is to recover sums in excess of the policy should make no difference. . . The difference is one of degree rather than form").

119 That is, courts should not assume that judgment in excess of policy limits is a good indication that refusal of an offer within policy limits was unreasonable. But see Crisci v. Security Ins. Co., 66 Cal. 2d 425, 431, 426 P.2d 173, 177, 58 Cal. Rptr. 13, 17 (1967). See note 49 supra.

130 This rarely will be the case, because the insured can neither accept nor reject a settlement offer under the terms of the standard liability policy, which reposes complete control of settlement negotiations in the insurer. See note 6 supra. There may be cases where the conduct of the insured could operate to estop him from making a bad-faith claim-as, for example, if he lied to the insurer. In such cases, the assignee would succeed to the estoppel problems of the assignor.

${ }^{121}$ Act of $1978 \S \S 101(40), 547,11$ U.S.C. $\S \S 101(40)$, 547 (Supp. II 1978). 


\section{Conclusion}

The insured's suit against his insurer for bad-faith refusal to settle a claim against the insured has serious conceptual and practical flaws, but is nonetheless necessary. No rational basis has yet been found, however, for allowing the third-party claimant to sue the insured's insurance company. Given the potential for widespread dislocations in the liability insurance system, none should be sought, especially by judicial inventiveness. The most a claimant should be able to urge is that the insured do his best to satisfy a judgment. To the extent that the insured's best interest is served by doing exactly that, no additional remedy is needed. To the extent that other factors intervene, the claimant should be able to use postjudgment garnishment procedures, which can be tailored to meet his needs without putting new strains on the insurance system and without contravening bankruptcy policies.

Diana C. White 